\title{
Four new records of Celastraceae for Brunei
}

\author{
I.A. Savinov \\ Department of Biology, Moscow State University of Food Production, \\ Moscow 125080, Russia \\ savinovia@mail.ru
}

\begin{abstract}
Four species belonging to three genera in the Celastraceae are reported here as new records for Brunei, Celastrus monospermus Roxb., Euonymus javanicus Blume, Salacia korthalsiana Miq. and S. maingayi M.A.Lawson. One species, Celastrus monospermus, is also the first record for Malesia. These species are discussed and details of the herbarium specimens in BRUN are provided.
\end{abstract}

Keywords. Borneo, Celastrus monospermus, Euonymus javanicus, Flora Malesiana, Salacia korthalsiana, Salacia maingayi,

\section{Introduction}

The Celastraceae, a medium sized family of angiosperms, consists of almost 100 genera and approximately 1350 species (Simmons, 2004). Southeast Asia is one of the main centres of diversity in the family. According to the revision of Celastraceae for Flora Malesiana (Ding Hou, 1962, 1964), there are 17 genera and 112 species in the region. In the Checklist by Coode et al. (1996), 30 species in 9 genera are listed for Brunei, among them seven undetermined species with remarks such as "sp. indet.", "sp. nov." and "sp.". On examination of unidentified specimens of Celastraceae in the BRUN herbarium, I have identified Celastrus monospermus Roxb., collected from Belait district, Euonymus javanicus Blume, collected from Temburong district, Salacia korthalsiana Miq., collected from Temburong district, and Salacia maingayi M.A.Lawson, collected from Belait district as new for Brunei. These species were not previously recorded from Brunei in the relevant literature (Coode et al., 1996), although in the work by Ding Hou $(1962,1964)$, general maps of distribution for some of the species enumerated above include northern Borneo but with insufficient detail to say if Brunei is included.

There is a second herbarium in Brunei, UBD Herbarium (UBDH), and recently a review of new plant records for Brunei based on the collections of this herbarium was published by Zamri \& Slik (2018). Two species of Celastraceae were published by them as new records for Brunei, Euonymus indicus B.Heyne ex Wall. and Lophopetalum pachyphyllum King. The specimens have been digitised and are available online. 


\section{Materials and methods}

During the $11^{\text {th }}$ Flora Malesiana Symposium (Brunei Darussalam, 30 June-05 July 2019), I had the opportunity to examine the collections at the Brunei National Herbarium (BRUN). Critical study of all available specimens of the Celastraceae (207 specimens, not including the genus Bhesa which has been transferred to the Centroplacaceae) enabled the identification of new records for the flora of Brunei from amongst previously unnamed material. Examination, identification and description of the specimens were done following standard taxonomic methods and consultation of the relevant literature (Blakelock, 1951; Ding Hou, 1955, 1962, 1964; Ma, 2001), which resulted in four new angiosperm records for the country. One species, Celastrus monospermus, is also the first record for Malesia.

\section{New records}

Celastrus monospermus Roxb., Fl. Ind. 2: 394 (1824). - TYPE: India, Desilva s.n. (lectotype NY [NY00337329], designated by Ding Hou (1955: 244)). (Fig. 1)

Specimens examined. BRUNEI: Belait: Bkt Sawat, Kpg Singap, Jln Kecil Singap., 4³3'N 114³5'E, 1 Aug 2008, Azlan BRUN 22409 (BRUN [BRUN031015]). Belait: Along Sungai Topi., $4^{\circ} 07^{\prime} \mathrm{N} 114^{\circ} 41^{\prime} \mathrm{E}$, Alt. 25 m, 24 Aug 1995, Ariffin Kalat BRUN 17052 (BRUN [BRUN007343]).

Notes. Celastrus monospermus differs from the closely related species Celastrus monospermoides Loes. in its stipitate fruit bases (the basal part strongly constricted and stipitate for 1-3 mm), the one-seeded capsules $17-20 \mathrm{~mm}$ long vs. 5-14 mm long in $C$. monospermoides, and the large cylindric seeds about $15 \mathrm{~mm}$ long and 8 $\mathrm{mm}$ wide vs. about $9 \mathrm{~mm}$ long and $5 \mathrm{~mm}$ wide in $C$. monospermoides. Both sheets of Celastrus monospermus in BRUN are in fruit. The two species also differ from each other in flower structure: a discoid disc in Celastrus monospermus vs. a flat disc in C. monospermoides (Ding Hou, 1955; Ding Hou et al., 2010). These characters may be useful in future field studies in Brunei. Another useful character is that the branchlets are often slightly zigzag in Celastrus monospermus vs. straight in Celastrus monospermoides (Ding Hou et al., 2010). The character is clearly visible on one of the specimens in BRUN (Fig. 1).

The closest published record of Celastrus monospermus to Brunei is a record from Southern Thailand (Phuket, Yala, Narathiwat - Ding Hou et al., 2010).

Euonymus javanicus Blume, Bijdr. Fl. Ned. Ind. 1146 (1827). - TYPE: Indonesia, Java, Blume s.n. (lectotype A! [A: 00049796], designated by Ma (2001: 171).

Specimen examined. BRUNEI: Temburong: Amo, Ulu Temburong NP, Base Camp, 9 Aug 2014, Low et al. LYW 727 (BRUN, two sheets [BRUN041553]). 


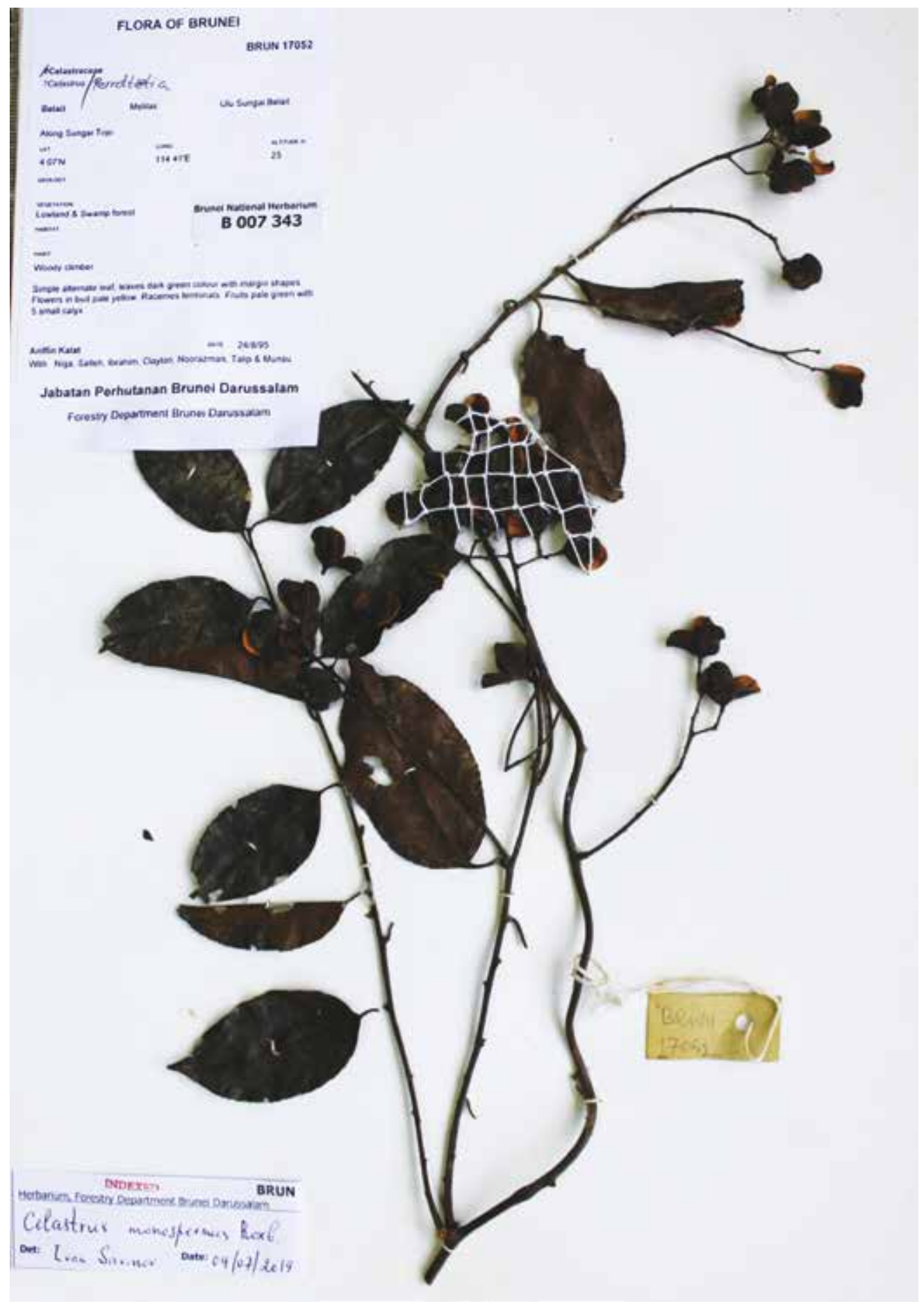

Fig. 1. Herbarium specimen of Celastrus monospermus Roxb., Ariffin Kalat BRUN 17052 (BRUN) (Photo: BRUN staff). 
Notes. The main differences between Euonymus javanicus and E. indicus B.Heyne ex Wall. are the number of flowers in the inflorescence (1 vs. 1-3), the position of the peduncles in the leaf axil (solitary/in pairs in E. javanicus vs. in cymes in E. indicus), and in the leaves (leaves generally flat in E. javanicus vs. veins often impressed above on leaves in E. indicus). Both species always have an "elaborate design" (using the term coined by Endress \& Matthews, 2006) of flower parts (a fimbriate margin to the petals). Many characters are variable and the differences between these two species (Blakelock, 1951: 256-257) are disputable, leading to some authors deciding to unite them (Ma, 2001; Ding Hou et al., 2010). Here I recognise them as distinct although note that if they are united that Euonymus indicus has priority. It has previously been reported only from SE Borneo (Téwe R.) (Ding Hou, 1962).

The specimen identified as Euonymus indicus? in UBDH (Brunei: Tutong, S.J. Davies L.814), cited by Zamri \& Slik (2018), and identified as "E. cf. javanicus B1." on the sheet label, has no flowers or fruits and its identification is uncertain.

Salacia korthalsiana Miq., Ann. Mus. Bot. Lugduno-Batavi 4: 152 (1869). - TYPE: Korthals s.n. (lectotype L [L0015409], designated by Ding Hou (1964: 407)).

Specimen examined. BRUNEI: Temburong: Temburong river just downstream from Kuala Belalong, 25 Jun 1989, Wong WKM 1264 (BRUN [BRUN007166]).

Notes. The species has distinctly peduncled axillary cymes (in contrast to the very short cymes for other species), a distinctly 5-lobed calyx (in contrast to an unlobed calyx in other species) and big elliptic or ovate-oblong leaves. In the past it was collected from Sarawak and Sabah states, and from the eastern part of Borneo in Kalimantan.

Salacia maingayi M.A.Lawson in Hooker, Fl. Brit. Ind. 1: 626 (1875). - TYPE: Maingay 398 (lectotype K [K000669970], designated by Ding Hou (1964: 417)).

Specimen examined. BRUNEI: Belait: Liang, Andulau FR (Sg Liang), 4³7'N 114²32'E, 23 Apr 2012, Ariffin Kalat 23199 (BRUN [BRUN031368]).

Notes. The species usually has 1 or 2 flowers in a leaf axil, clearly acuminate shining leaves, a large oblong 3-celled fruit, 4-6 cm diam. and several seeds (usually 6). It has previously been reported from Sarawak and Sabah (Ding Hou, 1964).

ACKNOWLEDGEMENTS. The author is grateful to the authorities at BRUN for giving permission for the study of their preserved specimens of Celastraceae, and personally to Joffre A. Ahmad, and also to the Organising Committee of the $11^{\text {th }}$ Flora Malesiana Symposium for partial financial support for his visit to Brunei Darussalam. Many thanks also to the management of the Moscow State University of Food Production for supporting the visit to Brunei. 


\section{References}

Blakelock, R.A. (1951). A synopsis of the genus Euonymus L. Kew Bull. 6(2): 210-290.

Coode, M.J.E., Dransfield, J., Forman, L.L., Kirkup, D.W. \& Said, I.M. (eds) (1996). A Checklist of the Flowering plants and Gymnosperms of Brunei Darussalam. Brunei Darussalam: Ministry of Industry and Primary Resources.

Ding Hou (1955). A revision of the genus Celastrus. Ann. Missouri Bot. Gard. 42(3): 215-302.

Ding Hou (1962). Celastraceae-I. In: Van Steenis, C.G.G.J. (ed) Flora Malesiana, ser. 1, vol. 6, pt. 2, pp. 227-291. Leiden: Noordhoff.

Ding Hou (1964). Celastraceae-II. In: Van Steenis, C.G.G.J. (ed) Flora Malesiana, ser. 1, vol. 6, pt. 3, pp. 389-421. Leiden: Noordhoff.

Ding Hou, Savinov, I.A. \& van Welzen, P.C. (2010). Celastraceae. In: Santisuk, T. \& Larsen, K. (eds) Flora of Thailand, vol. 10, pt. 2, pp. 141-198. Bangkok: Prachachon Co. LTD.

Endress, P.K. \& Matthews, M.L. (2006). Elaborate petals and staminodes in eudicots: Diversity, function, and evolution. Organisms Diversity Evol. 6: 257-293.

Ma, J.-S. (2001). A revision of Euonymus (Celastraceae). Thaiszia 11: 1-264.

Simmons, M.P. (2004). Celastraceae. In: Kubitzki, K. (ed) The families and genera of vascular plants, vol. 6, Flowering Plants, Dicotyledons, pp. 29-64. Berlin: Springer.

Zamri, A. \& Slik, J.W.F. (2018). Checklist of Seedplant holdings of the UBD Herbarium (UBDH), with 234 new plant records for Brunei Darussalam. Scientia Bruneiana. 17(1): 6-122. 
